\title{
The Immunomodulatory Effect of Elephantopus scaber and Sauropus androgynus Extract to Cellular Immune Response in Pregnant Mus muscullus Infected by Salmonella typhimurium
}

\author{
Nur Jannah ${ }^{1}$, Moch. Sasmito Djati ${ }^{2 *}$, Sri Widyarti ${ }^{2}$ \\ ${ }^{1}$ Master Program of Biology, Faculty of Mathematics and Natural Sciences, University of Brawijaya, Malang, Indonesia \\ ${ }^{2}$ Department of Biology, Faculty of Mathematics and Natural Sciences, University of Brawijaya, Malang, Indonesia
}

\begin{abstract}
Pregnancy has a high risk and is more susceptible to infectious diseases. E. scaber and S. androgynus contains saponins and flavonoids as an immunomodulatory that can increase the body's immunity. The purpose of this study is to determine the immunomodulatory effects of $E$. scaber and S. androgynus leaf extract against cellular immune response in pregnant mice infected $S$. typhimurium. This research used seven treatment groups including negative control (K-) mice without injected S. typhimurium, positive control $(\mathrm{K}+)$ mice were injected $S$. typhimurium and extract treatment with 5 variant doses and dissected on the $12^{\text {th }}$ and $18^{\text {th }}$ days. Lymphocytes was isolated from the blood, then relative number of $\mathrm{CD}^{+}$and $\mathrm{CD} 8^{+}$were analyzed with flow cytometry and data continued with ANOVA. Statistical analysis showed that different extract dose and duration of treatment had a significant effect on the number of $\mathrm{CD} 4^{+}$and $\mathrm{CD} 8^{+} \mathrm{T}$ cells. $E$. scaber and $S$. androgynus act as immunomudulatory effect and treatment with combination of extracts $E$. scaber and $S$. androgynus $50 \mathrm{mg} \cdot \mathrm{kg}^{-1} \mathrm{BW}+112.5 \mathrm{mg} \cdot \mathrm{kg}^{-1} \mathrm{BW}$ respectively and treatment with extract of $S$. androgynus $150 \mathrm{mg} \cdot \mathrm{kg}^{-1}$ BW are the optimum treatment which can restore immune system conditions such as normal pregnancy without infection.
\end{abstract}

Keywords: Cellular Immune, E. scaber, Immunomodulatory, S. androgynus, S. typhimurium.

\section{INTRODUCTION}

Typhoid fever is a disease with serious threat in developing countries because it can cause death; which is caused by $S$. typhimurium bacteria $[1,2]$. In humans, the infection is caused by a decline activity of immune system thus the immune system is incapable to kill the bacteria causing the bacteria to survive, thrive, invade and damage the body's cells [3].

Pregnancy is more vulnerable and have a high risk of infection because in pregnant condition, immunological conditions is unique [4]. Previous research indicated that typhoid fever because of Salmonella in pregnancy can cause abortion [5].

Typhoid fever is usually treated with antibiotics and synthetic antibacterial, but either of these medications provides teratogenic effects to fetus. Thus the fetus may be at risk of mental or physical disability [6]. One alternative to solve the problem is using herbs, which is harmless compare to synthetic drugs [7].

E. scaber and $S$. androgynus contains saponins and flavonoids known as a natural

\footnotetext{
* Correspondence author:

Moch. Sasmito Djati

Email : msdjati@ub.ac.id

Address : Laboratory of Animal Physiology, University of Brawijaya, Jl. Veteran Malang, 65145
}

immunomodulatory that can enhance the immune system [8]. Flavonoid compounds can improve the activity of IL-2 and lymphocyte proliferation. Lymphocyte proliferation active Th1 cells macrophage activation through cytokines IFN- $\gamma$ produced by $\mathrm{CD}^{+} \mathrm{T}$ cells and lysis of infected cells by $\mathrm{CD}^{+}$T cells $[9,10]$. Based on this background, this study aims to determine the immunomodulatory effects of $E$. scaber and $S$. androgynus leaf extract against cellular immune response in pregnant mice infected by $S$. Typhimurium, based on $\mathrm{CD}^{+} \mathrm{T}$ cells and $\mathrm{CD} 8^{+} \mathrm{T}$ cells in the blood.

\section{MATERIALS AND METHODS}

\section{Treatment Group}

Pregnant mice were obtained from PT. Galaxy Science Jember divided into seven groups (Table 1). Mice were infected with $S$. typhimurium on day 5 after the extract and the extract was continued until dissected on the $12^{\text {th }}$ and $18^{\text {th }}$ day.

\section{Isolation of Lymphocytes Cells}

Obtained blood put into propylene tubes that contained $10 \mathrm{ml}$ of RBC lysis and then centrifuged $300 \mathrm{rpm}$, for 5 minutes $10^{\circ} \mathrm{C}$ to obtain pellets. Then added RBC lysis again about $5 \mathrm{~mL}$ and then recentrifuged again. The pellet was added $1 \mathrm{ml}$ 
PBS and then centrifuged $300 \mathrm{rpm}$ for 2 minutes $10^{\circ} \mathrm{C}$. Pellets can be added as much as $1 \mathrm{ml} \mathrm{PBS}$ then resuspended and divided into 3 microtubes, each $300 \mathrm{~mL}$ then centrifuged at $2500 \mathrm{rpm}$, at temperature of $4^{0} \mathrm{C}$ for 5 minutes.

Table 1. Treatment Group

\begin{tabular}{|c|c|c|c|}
\hline \multirow{2}{*}{ Group } & \multicolumn{2}{|c|}{ Extract (mg.kg- ${ }^{1}$ BW) } & \multirow{2}{*}{$\begin{array}{c}\text { Infection } \\
\left(10^{7} \text { CFU.mL }{ }^{1}\right)\end{array}$} \\
\hline & E.scaber & S.androgynus & \\
\hline K- & - & - & - \\
\hline K+ & - & - & v \\
\hline $\mathbf{P}_{1}$ & 200 & - & v \\
\hline $\mathbf{P}_{2}$ & 150 & 37.5 & $\checkmark$ \\
\hline $\mathbf{P}_{3}$ & 100 & 75 & $v$ \\
\hline $\mathbf{P}_{4}$ & 50 & 112.5 & $\mathrm{v}$ \\
\hline$P_{5}$ & - & 150 & $\mathrm{v}$ \\
\hline
\end{tabular}

\section{Flowcytometry Analysis}

Pellets are added to the monoclonal antibody anti-mouse CD4 monoclonal antibody (BioLegend No. Cat. 100 531). The concentration is 0.01 $\mathrm{mg} \cdot \mathrm{mL}^{-1}$ and $50 \mu \mathrm{L}$ phycoerythrin (PE)-conjugated anti-mouse CD8 (BioLegend, No Cat. 100 708) with a concentration of $0.01 \mathrm{mg} \cdot \mathrm{mL}^{-1}$. Then it was incubated for 20 minutes in the ice box, then added $300 \mu \mathrm{L}$ PBS and resuspended. Later it transferred to the cuvet for flowcytometry analysis.

\section{Data Analysis}

This study used a completely randomized design factorial pattern. Data from the flow cytometry analyzed statistically with one-way ANOVA with a significance level of $p<0.05$ using SPSS, then followed by Tukey's test.

\section{RESULT AND DISCUSSION}

Result showed that the relative number of $\mathrm{CD}^{+}$and $\mathrm{CD}^{+} \mathrm{T}$ cells at day 12 in pregnant mice without infection $S$. typhimurium lower than infected pregnant mice by the $S$. typhimurium (Figure 1a). On the $18^{\text {th }}$ day of pregnant also showed the same result that the relative number of $\mathrm{CD}^{+} \mathrm{T}$ cells and $\mathrm{CD}^{+}$normal pregnant mice lower than infected pregnant mice. It was significantly different (Figure $1 \mathrm{~b}$ ). The increase is due to antigen enters to the body. It can enhance the immune response for the production of immunocompetent cells and increasing the proliferation and differentiation of $\mathrm{T}$ cells to antigen elimination which infect the body [11].

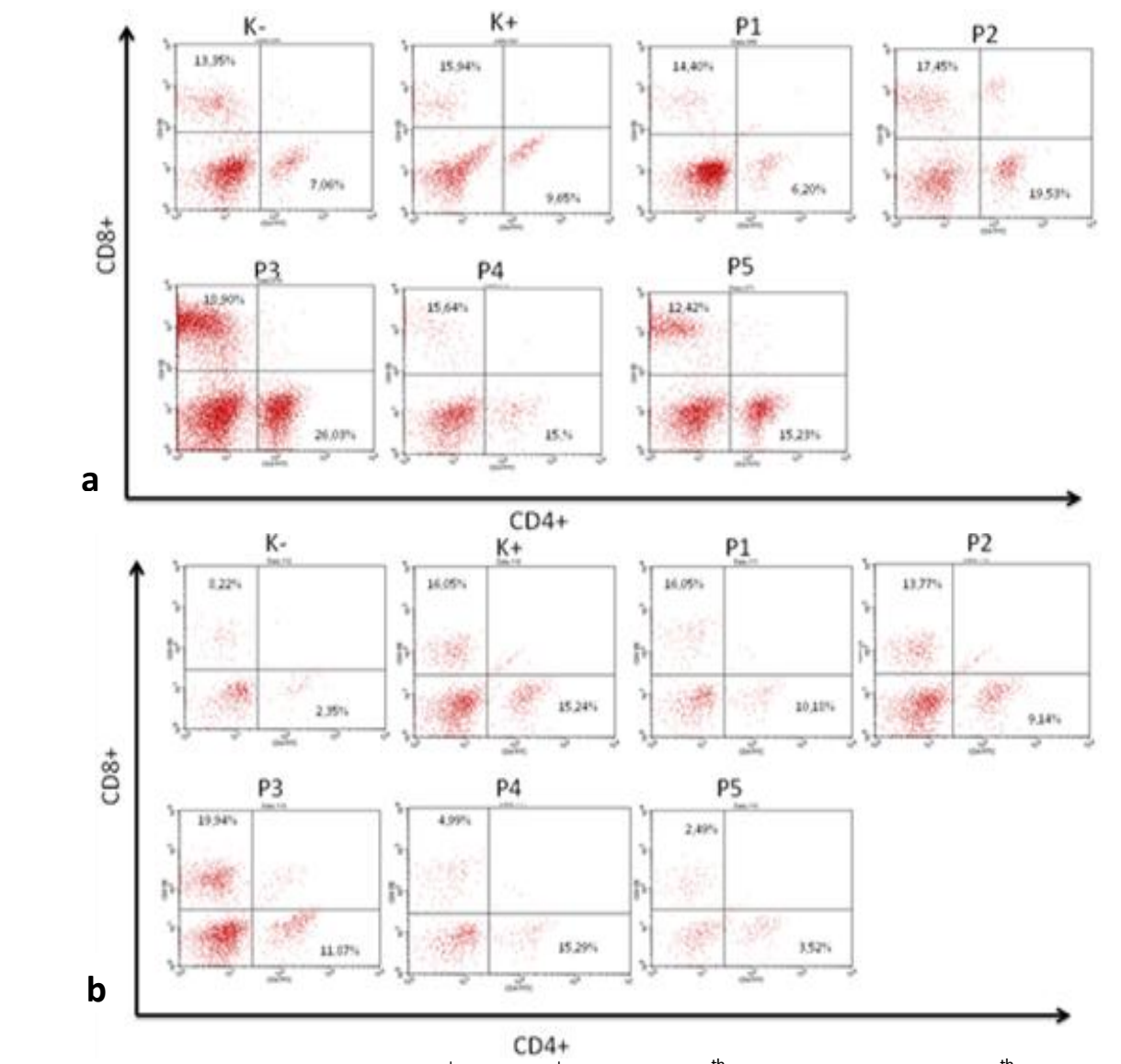

Figure 1. Profile of relative number $\mathrm{CD}^{+}$and $\mathrm{CD}^{+} T$ cells. (a) $12^{\text {th }}$ day of pregnancy; (b) $18^{\text {th }}$ day pregnancy 
The presence of Salmonella infection would induce Th1 cell responses and after infection, then $\mathrm{CD}^{+} \mathrm{T}$ cells are activated to increase the number of $\mathrm{CD}^{+} \mathrm{T}$ cells and cytokines [12]. $\mathrm{CD} 4^{+} \mathrm{T}$ cells contribute to activate macrophages, whereas the $\mathrm{CD}^{+} \mathrm{T}$ cells called cytotoxic $\mathrm{T}$ cells kill cells containing microbes in the cytoplasm resulting in a reservoir of infection [13].

The treatment of $E$. scaber and S. androgynus extract on day 12 showed a lack of regulation of immune system. It was observed through the number of $\mathrm{CD}^{+} \mathrm{T}$ cells were significantly different compared with the positive control (infected pregnant mice without treatment). $\mathrm{CD}^{+}{ }^{+}$cell number at treatment $E$. scaber extract $200 \mathrm{mg} . \mathrm{kg}^{-1}$ BW has $19.53 \%$ and E. scaber extract $100 \mathrm{mg} \cdot \mathrm{kg}^{-1} \mathrm{BW}$ and S. androgynus $75 \mathrm{mg} \cdot \mathrm{kg}^{-1} \mathrm{BW}$ has $26.03 \%$ (Figure 2). The relative number of $\mathrm{CD}^{+} \mathrm{T}$ cells on the $12^{\text {th }}$ and $18^{\text {th }}$ day of dissection show that treatment with $E$. scaber extract 100 mg. $\mathrm{kg}^{-1} \mathrm{BW}$ and S. androgynus $75 \mathrm{mg} . \mathrm{kg}^{-1} \mathrm{BW}$ has $18.90 \%$ and $19.94 \%$ (Figure 3 ). This increase is predicted because of the content of the two plants in the form of saponins and flavonoids. Both of these compounds contribute in cell proliferation that is able to induce synthesis the proto-oncogene c-fos and c-myc. The role of proto-oncogene on cell proliferation is increasing the mitogen signal transduction through the increased expression of cytokines IL-2 [14]. Flavonoids can increase IL-2 activity and lymphocytes proliferation [9]. IL-2 can trigger the $\mathrm{CD}^{+}$activation to $\mathrm{CD} 8^{+}$produce perforin and granzyme that will destroy infected cells [15].

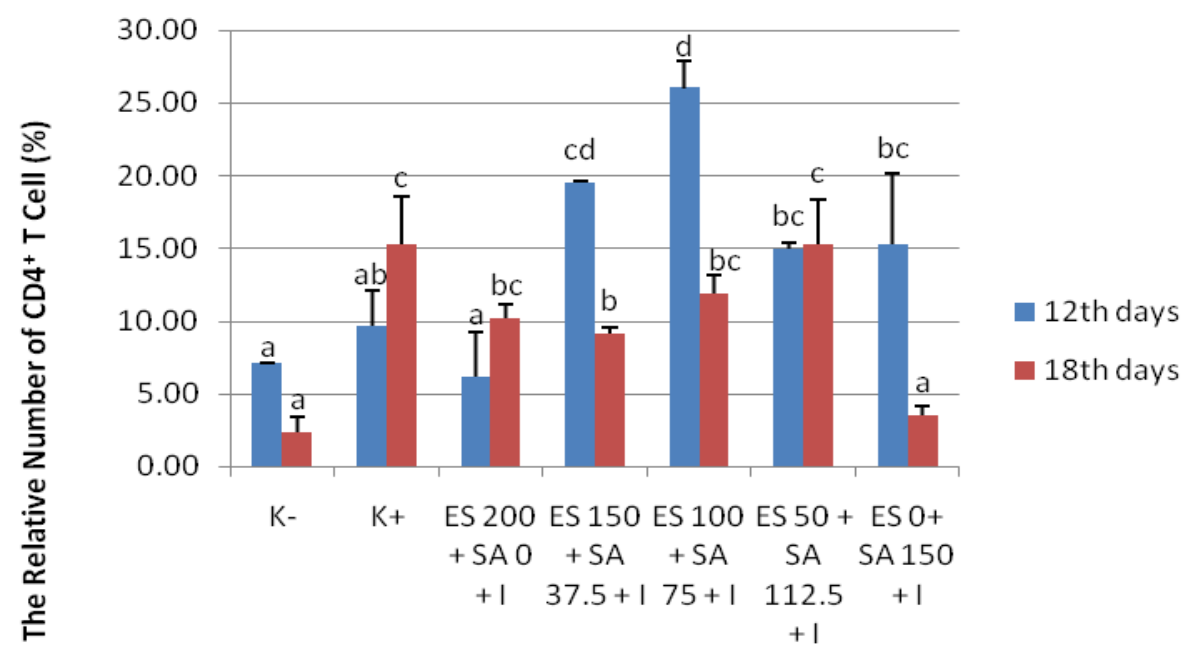

Figure 2. The relative number of $\mathrm{CD} 4^{+} \mathrm{T}$ cells. The dose and duration of administration of herbs affect the number of $\mathrm{CD} 4^{+} \mathrm{T}$ cells. Different notation indicates a significant difference $(P<0.05)$.

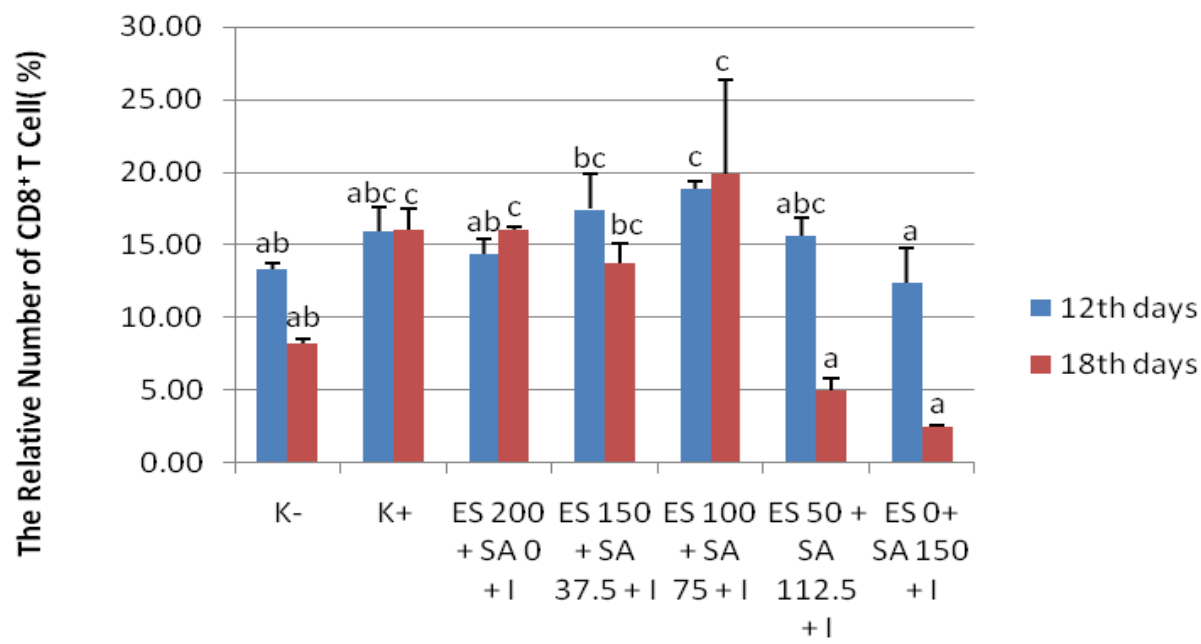

Figure 3. The relative number of $\mathrm{CD} 8^{+} \mathrm{T}$ cells. The dose and duration of administration of herbs affect the number of $\mathrm{CD} 8^{+} \mathrm{T}$ cells. Different notation indicates a significant difference $(P<0.05)$ 
The relative number of $\mathrm{CD} 4^{+} \mathrm{T}$ cells at the $18^{\text {th }}$ day of dissection in treatment $E$. scaber extract 150 mg. kg ${ }^{-1}$ BW has $9.14 \%$ and treatment $S$. androgynus extract 150 mg. kg ${ }^{-1}$ BW has $3.52 \%$ significantly decreased compared with a positive control (infected pregnant mice without treatment). The relative number of $\mathrm{CD} 8^{+} \mathrm{T}$ cells also showed the same result the treatment with extract $E$. scaber $50 \mathrm{mg} \cdot \mathrm{kg}^{-1} \mathrm{BW}$ and $S$. androgynus $112.5 \mathrm{mg} \cdot \mathrm{kg}^{-1} \mathrm{BW}$ has $4.99 \%$ and extract of $S$. androgynus has $2.49 \%$. It significantly decreased compared with a positive control. Saponins and flavonoids in addition act as immunostimulatory also serves as imunosupresor that suppresses the immune response. Both of these compounds are amphiphilic that can increase the level of Cyclin-Depedent-Kinase (CDK) inhibitor in the form of protein $\mathrm{P} 27^{\mathrm{KIP}}$ that play a role in the regulation of cell proliferation in phase G0/G1 by inhibiting compound G1 CyclinCDK resulting in cell cycle does not continue and the cessation of cell proliferation [16].

In pregnancy, the function of humoral and cellular immune suppression that occurred supression of Th1 and Tc cells which will reduce the secretion of IL-2, IFN- $\gamma$ and TNF- $\beta$. Suppression of Th1 response is needed to sustain a pregnancy [17]. In addition, pregnancy hormones such as progesterone, estrogen and prolactin are also affects the immune system that is able to minimize the effects of peripheral NK cells [18]. Treatment with combination of extracts $E$. scaber $50 \mathrm{mg} \cdot \mathrm{kg}^{-1} \mathrm{BW}$ and $S$. androgynus $112.5 \mathrm{mg} \cdot \mathrm{kg}^{-1} \mathrm{BW}$ and treatment with extract of $S$. androgynus $150 \mathrm{mg} \cdot \mathrm{kg}^{-1} \mathrm{BW}$ are the optimum treatment which can restore immune system conditions such as normal pregnancy without infection.

\section{CONCLUSION}

E. scaber and S. androgynus extract showed a significant difference to the number of $\mathrm{CD} 4^{+}$and $\mathrm{CD}^{+} \mathrm{T}$ cell in infected pregnant mice by $S$. typhimurium. Optimal treatment to help balance the immune system in pregnancy treated with a combination of extracts $E$. scaber $50 \mathrm{mg} . \mathrm{kg}^{-1} \mathrm{BW}$ and $S$. androgynus 112.5 mg. kg ${ }^{-1}$ BW and treatment P5 with $S$. androgynus extract 150 $\mathrm{mg} \cdot \mathrm{kg}^{-1} \mathrm{BW}$.

\section{ACKNOWLEDGEMENT}

Authors would like to thank Prof. Muhaimin Rifa'i, S.Si., Ph.D.Med.Sc and all those who have helped.

\section{REFERENCES}

[1] Srinivasan, A., M.S.G. Rosa, J. Michael, M.S. Michelle, L. Leo, J.M. Stephen. 2007. Innate immune activation of CD4 $\mathrm{T}$ cells in Salmonella infected mice is dependent on IL-18. J. Immunol. 178. 6342-6349.

[2] Dewi, P. 2007. Pengaruh pemberian ekstrak lidah buaya (Aloe vera) terhadap proliferasi limfosit pada Mencit BALB/c yang diinfeksi Salmonella typhimurium. Scientific Paper. Faculty of Medicine. Diponegoro University. Semarang.

[3] Ugrinovic, S., N. Menager, N. Goh, P. Mastroeni. 2003. Characterization and development of T-cell immune responses in B Cell deficient $\left(\mathrm{Igh}^{-6-/-}\right)$ mice with Salmonella enteric Serovar typhimurium Infection. Infect. Immun. 71. 6808-6819.

[4] Mor, G., I. Cardenas. 2010. The immune system in pregnancy: a unique complexcity. Am. J. Reprod. Immunol. 63(6). 425-433.

[5] Pejcic-Karapetrovic, B., K. Gurnani, M.S. Russell, B.B. Finlay, S. Sad, L. Krishnan. 2007. Pregnancy impairs the innate immune resistance to Salmonella typhimurium leading to rapid fatal infection. J. Immunol. 179. 60886096.

[6] Gondo, H.K. 2007. Penggunaan antibiotika pada kehamilan. Wijaya Kusuma. 1(1). 5762.

[7] Spelman, K., J.J. Burns, D. Nichols, N. Winters, S. Ottersberg, M. Tonborg. 2006. Modulation of cytokine expression by traditional medicines: a review of herbal immunomodulators. Alternative Med. Rev. 11. 128-146.

[8] Middleton, E.Jr., C. Kandaswami, T.C. Theoharides. 2000. The effects of plant flavonoids on mammalian cells: implication for inflammantion, heart disease, and cancer. Pharm. Rev. 2. 673-751.

[9] Liang, Q.L., Z. D. Min, Y.D. Tang. 2008. A new elemanolide sesquiterpenelactone from Elephantopus scaber, L. J. Asian Nat. Prod. Res. 10. 403-407.

[10] Abbas, A.K., A.H. Lichtman, S. pillai. 2007. Cellular and molecular immunology, $6^{\text {th }}$ edition. Saunders Elsevier. 66-67.

[11] Walton, R.E. 2008. Principle and practice of endodontic. Surnawinata (Transl.) EGC. Jakarta.

[12] Mittrucker, H.W., S.H. Kaufmann. 2000. Immune Response to Infection with Salmonella typhimurium in Mice. J. Leukocyte Biol. 67(4). 457-463. 
[13] Abbas, A.K., A.H. Litchman. 2011. basic immunology 3e updated edition. Philadelphia: Elsevier. 103-107, 113-121.

[14] Chen, H.L., D.F. Li, B.Y. Chang, L.M. Gong, X. Piao, G.F. Yi, J.X. Zhang. 2003. Effects of lentinan on broiler splenocyte proliferation, interlaukin-2 production, dan signal transduction. J. Poultry Sci. 82. 760-766.

[15] Mc Nally, A., R.H. Geffery, S. Tim, T. Ranjeny, J.S. Raymond. 2011. $C D 4^{+} \mathrm{CD} 25^{+}$regulatory $\mathrm{T}$ Cells Control $\mathrm{CD}^{+} \mathrm{T}$ cell effector differentation by modulating IL-2 homeostasis. PNAS. 8. 7529-7534.

[16] Wang, J.X., W. Tang, L.P. Shi, Wan, R. Zhou, J. Ni, Y.F. Fu, Y.F. Yang, Y. Li, J.P. Zuo, 2007. Investigated of the immunosupressive Activity of Artemetho on T-Cell activation and proliferation. J. Pharmacol. 150. 652-661.

[17] Cunningham, F., M.D. Gary, J. Leveno, M.D. Kenneth, L. Bloom, M.D. Steven, C.J. Hauth. 2010. Human Immunodeficiency Virus. Williams Obstetrics $23^{\text {rd }}$ Ed. 1246-1253.

[18] Dosiou, C., L.C. Giudice. 2005. Natural killer cells in pregnancy and recurrent pregnancy lloss: endocrine and immunologic perspective. Endocr. Rev. 26(1). 44-62. 